\title{
PERBUDAKAN MODERN (MODERN SLAVERY) (ANALISIS SEJARAH DAN PENDIDIKAN)
}

\author{
MUHAMAD TISNA NUGRAHA
}

\begin{abstract}
Penulis adalah dosen mata kuliah Sejarah Peradaban Islam di Fakultas Tarbiyah dan Ilmu Keguruan (FTIK) Institut Agama Islam Negeri (IAIN) Pontianak
\end{abstract}

\begin{abstract}
Slavery is a form of employing a person and putting him/her under the control of another. Such control includes restriction, use of physical energy or perhaps even his/her mind without compensation such as a decent wage or other forms of respect. Slavery does not always appear in the form of physical pressure, but it can also be in the psychological form by demanding someone to do something for the interests of another due to power, indebtedness or religious texts.

Traces of slavery in the course of human history, in fact, have been found since ancient times in Mesopotamia, Egypt, Europe or Arabia. It can also be found in the practice of Abrahamic religions such as Judaism, Christianity, and Islam. So it is undeniable that slavery is not a novelty and will always appear in the historical journey of human life with a variety of forms. The Islam religion brought by Prophet Muhammad (pbuh), as one of the Abrahamic religions is basically against slavery. It can be seen from the history and from its teachings against the practice of slavery. Islam also strongly advocates respect for the rights of a slave especially for labor. Therefore, all forms and manifestation of slavery, including in the field of education must be resolved immediately.
\end{abstract}

Keywords: modern slavery, education, political salery, social stravery, abrahmic religious and industrial slavery

\section{PENDAHULUAN}

Sejarah perbudakan telah berlangsung cukup lama dalam perjalanan historis kehidupan manusia di muka bumi. Di Mesir, Ramses II seorang fir'aun yang berkuasa pada tahun 1290-1224 SM telah melakukan ekspansi kekuasaanya secara signifikan, yang ditandai dengan banyaknya penaklukkan ke berbagai negeri yang diikuti dengan semangat perbudakan bagi penduduk yang telah ditaklukannya. Diantara orang-orang yang diperbudak adalah berasal dari Libanon, Suriah, dan termasuk juga kota "Shalem", yaitu nama kuno dari kota Yerusalem.

Selanjutnya ketika Romawi dipimpin oleh keturunan Raja Romulus sampai pada zaman bangsa Etrutia, yang diakhiri dengan kudeta warga negaranya hingga berganti menjadi sistem pemerintahan republik. Romawi kemudian menjadi salah satu bangsa penguasa besar dengan turut melakukan ekspansi sampai ke Laut Tengah. Bangsa yang pada awalnya mengantungkan hidup pada sektor agraris ini, kemudian menjadi mas- 
yarakat kapitalis, materialis, dan gemar akan perang dan perbudakan, sehingga pada beberapa abad kemudian, negara kota Romawi berubah menjadi sebuah mesin perang yang menghancurkan negara-negara disekitarnya.

Ambisi perluasan wilayah dari polis Romawi terhadap wilayah lainnya tersebut, menuai protes bahkan perlawanan yang sengit dari berbagai wilayah. Puncaknya adalah pecahnya perang Punisia atau Perang Punik yang pertama, dimana Republik Romawi pada awal peperangan sempat menderita kekalahan, namun dengan kerjasama dan dukungan negara-negara sekutu yang sebagian besar berada di wilayah Italia dan sekitarnya, mereka pada akhirnya berhasil memaksa polish Kartago untuk menyerahkan wilayah Sisilia yang dilanjutkan dengan penaklukkan wilayah kepulauan Korsika dan Sardinia.

Beberapa tahun kemudian, yakni sekitar tanggal 19 Oktober 202 SM Romawi kembali melancarkan serangannya ke Kerajaan Karthago, sehingga meletus Perang Punisia ke 2. Ketika itu, kerajaan Karthago menunjuk Hannibal Barca (247-195 SM) sebagai komandan yang membawa gajah-gajah perang dan sejumlah besar pasukan kavaleri untuk menghancurkan barisan tentara Romawi. Mereka berhasil melintasi jalan-jalan sempit di pegunungan Alpen di Prancis yang curam dan bersalju serta menembus pertahanan Romawi hingga ke bagian Barat Italia. Namun setelah meletus perang Punisia III pada 149-146 SM ibu kota Karthago secara resmi berhasil ditaklukan dan menjadi bagian koloni Republik Romawi.

Hampir seluruh penduduk yang tersisa di Karthago dijadikan budak lalu dijual, sisanya dibunuh dengan kejam oleh tentara Romawi. Tidak hanya berhenti di dua negara besar seperti Makedonia dan Karthago, ambisi Romawi kembali ditunjukkan dengan mengakusisi Yunani pada tahun 146 SM. ${ }^{1}$ Pada masa inilah dikenal sebagai Zaman Perbudakan atau "Age of Slavery" yang terbesar dan terkejam sepanjang sejarah kehidupan manusia.

Pada era kekinian, perbudakan masih dapat ditemukan. Misalnya pada lingkup Indonesia, beberapa tahun yang lalu telah ditemukan praktek perbudakan di sebuah pabrik di kawasan Tangerang. Bentuk dari perbudakan tersebut adalah minimnya upah kerja, suasana tempat kerja yang kurang kondusif dari segi kesehatan, dan kurangnya fasilitas-fasilitas pendukung bagi kenyamanan dan kesejahteraan para karyawannya.

Begitu juga pada tahun 2015 ini, sebuah "kasus perbudakan" terjadi pada para nelayan di sebuah kapal asing yang ditemukan di perairan Indonesia. Namun, lebih dari itu, ada beberapa bentuk perbudakan yang dapat ditemukan pada era sekarang. Beberapa diantaranya misalnya perdagangan tenaga manusia atau yang dikenal dengan istilah human trafficking, pengkoordinasian orang-orang dewasa hingga anak kecil untuk menjadi penyandang masalah sosial seperti pengemis, pengamen jalanan, dan sebagainya. Kemudian pengendalian prostitusi oleh para germo atau mucikarinya juga bentuk lain dari perbudakan yang dapat kita lihat dan temukan di era sekarang ini.

1 Meskipun Romawi dalam sejarahnya berhasil mengusai Yunani, tetapi sepreti terjadi dimana-mana, justru kebudayaan Yunanilah yang dominan. Bahkan meskipun kekuasaan Yunani telah dikalahkan Romawi, namun justru kebudayaan Yunani lah yang berhasil mengalahkan kebudayaan yang dibawa oleh Romawi. 


\section{PERBUDAKAN DALAM}

PERSPEKTIF AGAMA DAN

\section{SEJARAH}

\section{Perbudakan dalam Tinjauan Agama}

Kamus Inggris- Indonesia dalam Anwar Thosibo (2002: 4) mengungkapkan bahwa kata slavery atau yang berarti 'perbudakan' atau 'bekerja keras". Sementara di dalam Kamus Umum Bahasa Indonesia budak berarti 'hamba' atau 'anak-anak'. Dengan kata lain, istilah "slavery", yang dalam hal ini mempunyai kesan penindasan, sama pengertiannya dengan penghambaan, ketergantungan, serta hubungan dyadik yang lebih manusiawi. ${ }^{2}$ E. Martasudjita (2003: 40-41), menyatakan bahwa budak itu tanpa hak yang ia miliki hanyalah kewajiban. Ia harus melayani tuannya kapanpun juga. Seorang budak tidak mempunyai kuasa apa-apa bahkan atas hidupnya sendiri. Ia hidup demi tuan dan majikannya. Ia harus siap setia saat melaksanakan perintah tuannya. ${ }^{3}$

Sedangkan kata hamba atau budak dalam bahasa Arab yang disebut 'abdun (budak laki-laki) atau 'amatun (budak perempuan). Kata ini satu akar dengan kata 'ibdah atau 'ibadah, sehingga ibadah dapat diartikan sebagai ekspresi penghambaan seseorang terhadap sang khalik, yaitu Allah SWT. ${ }^{4}$ Dalam bahasa Yunani, kata 'hamba (budak)' maupun "anak" adalah paisa atau paidos. Dalam bahasa Indonesia kuno (Melayu) "budak" adalah juga "anak". 5 Sehingga dibeberapa

2 Anwar Thosibo. Historiografi Perbudakan Sejarah Perbudakan di Sulawesi Selatan Abad XIX. (Magelang : IndonesiaTera. 2002). hlm. 4

3 E. Martasudjita. 2003. Pelayanan yang Murah Hati. (Yogyakarta : Kanisius. 2003). hlm. 40-41

4 Ahmad Hadi Yasin. Meraih Dahsyatnya Ikhlas. (Jakarta: AgroMedia Pustaka. 2010). hlm. 38.

5 Tim Balitbang. Meretas Jalan Teologi Agama-Agama di Indonesia: Theologia Religionum. (Jakarta: BPK Gunung Mulia. 2007). hlm. 114. wilayah Melayu, anak-anak juga sering dipanggil dengan sebutan budak-budak, semisal di daerah Pontianak Kalimantan Barat.

Kata budak dalam Islam dan ajaran Nasrani tidak dapat disamakan. Seseorang dalam Islam tidak diperbolehkan menyebut budaknya dengan kata "hamba" karena dengan kata ini digunakan oleh Allah dan Rasul-Nya dalam banyak kesempatan. Sehingga budak laki-laki dipanggil 'abd dalam bahasa Arab dan amat untuk budak perempuan, dan sayyid atau rabb untuk pemiliknya atau tuannya. Budak disebut pula dengan kata mamlu$u k$, dan budak perempuan dengan kata fataat ${ }^{6}$

Pernyataan ini menggeser tatanan hierarki masyarakat yang telah mapan dan sarat dengan ketimpangan sosial. Kedudukan terhormat tidak lagi ditentukan oleh status sosial, kekayaan, kedudukan, jabatan, keturunan, megahnya singgasana dan atribut lainnya, melainkan tulusnya perbuatan atau dengan kata lain "pelayanan". Artinya, siapa yang dengan tulus tanpa tedeng aling-aling berbuat untuk sesamanya, dialah yang terbesar diantara sesamanya. Hal ini sebagaimana terdapat dalam Injil Markus; "Barangsiapa ingin menjadi besar diantara kamu, hendaklah ia menjadi pelayanmu, dan barangsiapa ingin menjadi yang terkemuka diantara kamu, hendaklah ia menjadi hamba untuk semuanya" (Markus. 10: 43-44). ${ }^{7}$ Semangat ini juga didasari oleh sabda Yesus "putera manusia datang bukan untuk dilayani, melainkan untuk melayani" (Mathius. 20: 28). ${ }^{8}$ Artinya Yesus memang anak manusia, tetapi ia datang

6 Imam Az-Zabidi. Ringkasan Shahih Al-Bukhari. (Bandung: Mizan Pustaka. 2008). hlm. 956.

7 Surbakti E. B. Benarkah Injil Kabar Baik?: Bagaimana Menyatakannya dalam Perspektif Lokal. (Jakarta: Gunung Mulia. 2008). hlm. 112.

8 Ignatius Suharyo. Gereja yang Melayani dengan Rendah Hati. (Yogyakarta: Kanisius. 2009). hlm. 110. 
atau berarti "diutus dan ditugaskan oleh Allah" untuk melayani, bukan untuk tampil sebagai tokoh yang berkuasa yang memerintah dan menghakimi. ${ }^{9}$

Kelak setelah bangsa Romawi pada tahun 300-an memeluk tradisi Kekristenan, masalah perbudakan tetap ada dan tidak mengalami banyak perubahan. Bahkan William Barclay (2010) menulis bahwa ;

"Perbudakan di mulai ketika Romawi menaklukan banyak wilayah dan para budak itu adalah para tawanan perang. Awalnya Romawi memiliki sedikit budak, tetapi pada masa Perjanjian Baru jumlahnya mencapai jutaan". ${ }^{10}$

Lebih lanjut, William Barclay juga mengungkapkan ketidakberdayaan gereja pada masa itu untuk mendorong para budak agar bangkit melawan tuan-tuan mereka, karena hal ini dikhawatirkan malah akan mengakibatkan terjadinya bencana. ${ }^{11}$ Sebagaimana pernah terjadi pemberontakan kaum budak akibat persoalan ini sebelumnya, namun dengan cepat dan kejam mereka dihancurkan tentara Romawi. Dalam setiap peristiwa, pengajaran tentang kemerdekaan kaum budak bukanlah suatu hal yang baik, hal ini malah menjadi suatu bumerang yang pada akhirnya akan membuat kekristenan di-

9 C. Groenen OFM \& Stefan Leks. Percakapan Tentang Mengikuti Yesus. (Yogyakarta: Kanisius. 1987). hlm. 151.

10 William Barclay. Pemahaman Al-Kitab Setiap Hari: Surat Yakobus 1 dan 2. (Jakarta: Gunung Mulia. 2010). hlm. 334.

11 Lihat William Barclay. ibid. hlm. 338. Yang menyatakan bahwa Rasul Petrus berpendapat bahwa para budak Kristen harus memperlihatkan pada dunia bahwa kekristenan tidak membuatnya menjadi pemberontak karena ketidak puasan, namun justru menghasilkan kaum pekerja yang telah menemukan ilham baru untuk dapat melakukan pekerjaannya setiap hari dengan jujur. cap sebagai agama yang subvesif atau memberontak pada pemerintahan yang sah. Untuk itu H. Berkhof (2009) juga menyatakan bahwa orang Kristen pada masa itu memandang perbudakan sebagai suatu perkara yang tidak dapat dihindari. Mereka itu pun mempunyai budak, dan budak Kristen dinasehati, supaya melayani tuannya dengan patuh, tulus ikhlas dan sabar. ${ }^{12}$ Pendapat ini sejalan dengan kisah Paulus yang meyakinkan seorang budak bernama Onesimus untuk kembali pada tuan-nya yang bernama Filemon sambil membawa surat pendek dari Paulus sebagai jaminan keselamatan diri si budak. ${ }^{13}$

Tradisi ini pula yang kemudian menjadi tradisi abadi kaum imperialis Eropa di abad 14-18 termasuk diantaranya penjajah Belanda di Indonesia. J. L. Ch. Abineno menyatakan, bukan hanya V.O.C sebagai pemerintah yang memiliki hamba-hamba atau budak-budak, tetapi juga pribadi-pribadi; hampir tiap-tiap orang Belanda mempunyai hamba atau budak, begitu juga pendeta-pendeta. Valentin umpamanya mempunyai 20 hamba atau budak. Leydecker yang kemudian terkenal sebagai penerjemah Kitab Suci mempunyai banyak hamba atau budak yang dipekerjakan di sebidang tanahnya, tidak jauh dari Betawi.

Selain dari padanya banyak pendeta yang mempunyai salah satu atau dua orang hamba atau budak. Dalam salah satu suratnya yang dituliskan pada tanggal 12 Juni 1629 , Gereja di Belanda (Klasis Walcheren) bertanya kepada Majelis Jamaat di Betawi apakah pemilikan hamba-hamba atau budak-budak oleh orang Kristen tidak harus dianggap se-

12 Hendrikus Berkof. Sejarah Gereja (Jakarta: Gunung Mulia. 2009). Jakarta: Gunung Mulia). hlm $15-16$.

13 Stephen M. Miller. User's Guide to Bible (Yogyakarta: Kanisius. 2009). hlm. 111. 
bagai sesuatu yang buruk dan yang karena itu dilarang? Atas pertanyaan itu Majelis Jamaat di Betawi tidak pernah memberikan jawaban. ${ }^{14}$

Jika melihat kembali ke belakang masalah perbudakan ketika agama Nasrani muncul, merekapun sepertinya tidak dapat menentang perbudakan. Juga tidak menganjurkan orang-orang beriman supaya menjauhkan generasi mereka dari sistem perbudakan. Rasul Paulus sendiri memerintahkan supaya budak untuk taat kepada tuannya, seperti mereka taat kepada Jesus. Dalam Perjanjian Baru, Surat Kiriman kepada Orang Ephesus 6: 5-8, dikatakan:

"Hai segala hamba, hendaklah kamu menuruti perintah orang yang menjadi tuanmu di dalam perkara dunia dengan takut dan gentar, serta tulus hatimu seperti kepada Kristus. Bukannya dengan berpura-pura seperti hendak menyukakan orang, melainkan seperti hamba Kristus, yang melakukan kehendak Allah daripada hati. Dengan rela bekerja seperti kepada Tuhan dan bukannya kepada manusia. Sebab mengetahui apa yang baik diperbuat masing-masing, itulah juga diterimanya daripada Tuhan, baik hamba, baik merdeka".

Sesudah jamaat Kristen melewati periode-periode penganiayaan yang berat oleh Kekaisaran Romawi, sebuah kebetulan terjadi manakala Kaisar Konstantin yang menghadapi perang berat di Jembatan Milivian pada tahun $312 \mathrm{M}$ atau juga dikenal dengan perang Pons Melivus memeluk agama Kristen. Mereka mendapatkan peluang kebe-

14 J. L. Ch. Abineno. Diaken (Diakonia dan Diakonat Gereja). (Jakarta: BPK Gunung Mulia. 2005). hlm. 55. basan setelah beratus-ratus tahun mengalami penindasan di bawah imperium Romawi terutama ketika Kaisar Konstantin mengeluarkan "Edict of Milan" tahun 313 M yang isinya adalah larangan Kaisar Konstantin terhadap semua penindasan bagi penganut monotheisme di Romawi. ${ }^{15}$ Keputusan ini juga memberikan angin segar khususnya terhadap tokoh-tokoh Kristen untuk menjadi bagian dari administrasi pemerintahan Kekaisaran Romawi. Dari sinilah bahkan dapat dikatakan tumbuh dan berkembangnya Kristen tidak terlepas dari peran dan jasa Kaisar Konstantin. Kemudian, titik balik Kristenisasi selanjutnya adalah klausa hubungan baru antara gereja dan pemerintahan Romawi. Hubungan ini menghasilkan pengakuan bahwa agama Kristen sebagai agama resmi negara yang menyebabkan pertaubatan massal dari para pengikut ajaran Dewa-Dewa Yunani.

\section{Praktik Perbudakan dalam Islam}

Perbudakan dalam Islam berkembang pesat di zaman kekhalifahan dengan mewarisi tradisi negara-negara sebelumnya yang berasal dari Mesir, Yunani, Romawi, dan Persia yang sudah ada sejak sebelum tahun Masehi. Hal ini sebagaimana dijelaskan oleh Philip K. Hitti (2002: 426) yang menyatakan bahwa pada saat itu hampir semua para pembantu yang ada di masa kekahalifahan adalah budak yang direkrut secara paksa dari kalangan non muslim, baik yang ditawan pada masa perang atau dibeli pada masa damai. Beberapa diantarannya adalah negro, dan ada juga orang kulit putih dan Turki. Budak berkulit putih (mamamlik) kebanyakan berkebangsaaan Yunani, Slavia, Armenia dan Berber. Budak-budak yang bekerja di keputren adalah

15 Adian Husaini. Wajah Peradaban Barat Dari Hegemoni Kristen ke Dominasi Sekular-Liberal. (Jakarta: Gema Insani Press. 2005). hlm. 31. 
laki-laki yang dikebiri (khishyan). Budak-budak lainnya yang juga dikebiri, yang dikenal dengan sebutan ghilman, menjadi kesayangan para tuannya, mengenakan busana yang mahal dan menarik, dan sering berhias dan mengharumkan tubuh mereka mirip perempuan. ${ }^{16}$ Disinilah Islam tidak menutup-nutupi persoalan tentang adanya perbudakan tersebut, bahkan hal ini juga diatur pergaulannya dalam beberapa ayat dalam al-Qur'an.

Berbicara tentang perbudakan dalam kajian historis dan perspektif Islam, hal ini tidak dapat dipisahkan dengan kehadiran Muhammad sebagai pembawa pesan ilahi dan penjelas ayat-ayat yang terdapat dalam Al-Qur'an. Muhammad bin Abdullah bin Abdul Muthalib adalah Nabi dan Rasul terakhir (hattam al-anbiya) yang telah dijanjikan kehadirannya dalam kitab suci agama-agama samawi. Van den End dan Christiaan de Jonge (1997) memberikan sedikit penjelasan tentang nubuwwat (ramalan) kedatangan Muhammad dalam Al-Kitab, dimana pada Perjanjian Baru berbahasa Syiria terdapat kata "parakletos" yang disalin sebagai kata Munhammana, dan kata ini dalam bahasa Arab bisa diterjemahkan sebagai Muhammad. Akan tetapi, para penafsir yang dengan cara ini melihat nubuwwat Muhammad dalam Perjanjian Baru tampaknya belum menghubungkan nubuwwat itu dengan surah 61: 1. Walaupun begitu, bagi orang-orang Kristen di masa lalu yang telah masuk Islam, hal itu sangat penting bahwa mereka telah menemukan hubungan dalam Perjanjian Baru dengan nubuwat Nabi dan Rasul terakhir sebagaimana yang telah dijanjikan dalam kitab mereka dan kitab-kitab terdahulu. ${ }^{17}$ Muhammad sendiri yang diang-

16 Philip K. Hitti. Terj. Yasin dan Riyadi. Hiistory Of The Arabs. (Jakarta: PT. Serambi Ilmu Semesta 2002). hlm. 426

17 Van den End dan Christiaan de Jonge. Sejarah gap sebagai parakletos dalam bahasa Alkitab telah beberapa kali muncul di dalam Injil Yohanes semisal pada ayat berikut:

"Dan aku akan meminta kepada Napa, dan Dia akan memberikan kepadamu seorang "paraclete" (Injil Yohanes (14) : 16, Versi Douay)

Istilah paraclete (parakletos) pada ayat injil Yohanes tersebut berasal dari kata parakletos (dibaca: par-ak'-lay-tos) yang berarti seorang penghibur, seorang pembela, penasihat atau pengacara. David Benjamin Keldani $^{18}$ (Armansyah, 2008), menyebutkan bahwa apabila istilah parakletos dialihkan ke dalam bahasa Ibrani maka akan menghasilkan kata hamida, yang juga memiliki akar kata sama seperti Ahmad atau Muhammad dalam bahasa Arab (H-M-D). ${ }^{19}$

Terlepas dari nubuwat tersebut, bagi umat Islam, Muhammad adalah suri tauladan yang baik dalam menyikapi persoalan perbudakan. Meskipun ia lahir tahun 570 Masehi atau tertinggal 2500 tahun lebih dibandingkan masa kejayaan perbudakan, Muhammad terbukti telah mengulangi kesuksesan Nabi Musa AS yang membebaskan orang-orang Yahudi dari perbudakan Fir'aun sebagaimana diirayakan dalam pesta Passover (Hari Raya Paskah Yahudi, dan dikisahkan dalam Ki-

Perjumpaan Gereja dan Islam. (Jakarta: Sekolah Tinggi Teologi Jakarta. 1997) hlm. 193.

18 David Benjamin Keldani (1867 M) adalah seorang Uskup Katolik Uraimah (Aramik) dari gereja United-Chatolic-Chaldaen. Ia pernah mengajar di Archbishop of Cantebury's Mission bagi Assyirian (Nestorian) Christians di Urmia dan juga terlibat sebagai perwakilan di kongres-kongres Katolik di pelbagai negara. Pada tahun 1904, David Benjamin Keldani memeluk agama Islam dan mengganti namanya menjadi Abdul Ahad Dawud.

19 Armansyah. Ramalan Imam Mahdi Akankah Ia Datang Pada 2015. (Jakarta: Serambi. 2008). hlm. 64-65. 
tab Keluaran 12: 23-27). ${ }^{20}$ Namun apa yang dilakukan Muhammad jauh lebih persuasif dan universal jika dibandingkan Nabi Musa As yang terlebih dahulu telah memberikan tekanan kepada tuan-tuan mereka termasuk Fir'aun untuk membebaskan orang-orang Yahudi. Termasuk golongan yang dibebaskan oleh Nabi Musa AS pada saat itu hanyalah golongan Yahudi saja dan berbeda dengan Muhammad SAW.

Muhammad SAW telah melewati batas lingkup sosial masyarakat dan negara yang ada pada saat itu. Diantara golongan budak yang telah dimerdekakan oleh Muhammad SAW adalah orang-orang Arab sendiri, Afrika, Persia dan bangsa-bangsa lainnya ketika itu, seperti: Zaid bin Harits (bekas budak Khadijah yang telah diangkat sebagai anak), Usamah bin Zaid, Tsauban bin Muhammad, Abu Rafi' (Aslam), Syarqan, Rabah, Nuby, Jazr Nubuy, Dhamrah bin Abi Dhamrah, Ma'bur al-Qibthy, Abu Muwaihibah, Safinah, Anisah, Aflah, Ubaidah, Thuman, Hunain, Sandar, Waqid, 'Asib, Abu Waqid, Qusam, Hatim, Ubaid bin Abdul Ghifay, Zaid bin Mula, Sa'id bin Azid, Abdullah bin Aslam, Ghajalan, Khairab, Muhammad bin Abdurrahman, Abu Makhul, Nafi' bin Saib, Nuhalk, Abu Qabilah, Abul Jusr, Salman al-Farisi, Ruwaifi', Hurmuz, Syam'un bin Zaid, Abu Salma, Abu Lubadah, Maimub, Abu Laqitha, Abu Hindun, Abu Ailah, Ummu Aiman (Barakah), Ummu Rafi', Umaimah, Sirin (saudara perempuan Maria al-Qibthiyah), Radhwa, Sadisah, Ummu Shabih, Khudairah, Ummu Dhamrah, Maimunah binti 'Asib, Ummu 'Ayyasi, Razinah, Basaniyah, Raisyahah, dan Maimunah binti Abasyah.

Moenawar Chalil (2001), menyatakan

20 Karen Armstrong. Perang Suci Dari Perang Salib Hingga Perang Teluk. Terj. Hikmat Darmawan. (Jakarta: Ikrar Mandiriabadi. 2003). hlm. 332. bahwa budak yang dimerdekakan Muhammad SAW, sebagian berasal dari pemberian orang lain, sebagian beliau beli sendiri, dan sebagian kecil yang dibawa oleh isteri beliau. Sehingga menurut riwayat, waktu Nabi SAW hampir wafat, beliau telah memerdekakan empat puluh orang budak. ${ }^{21}$ Muhammad juga telah menginspirasi orang-orang Muslim lainnya untuk melakukan apa yang telah dilakukannya. Semisal Abu Bakar (khalifah pertama dan sahabat Nabi) yang telah membebaskan Abu Fukaifah, Amir bin Fuhairah, Labibah dan Bilal bin Rabah, seorang budak dari negeri Habasyah yang kelak akan menjadi seorang Muazin terkenal dalam sejarah Islam. Selain itu ada juga Utsman bin Affan (khalifah ketiga dan sahabat Nabi) yang dalam buku Fikih Sirah ditulis Lutfi Fathullah (2009) menyebutkan bahwa tercatat tidak satu pun shalat Jum'at yang kulewati sejak aku memeluk Islam, kecuali aku pasti memerdekakan seorang budak di hari itu. Kalaupun aku sedang mengalami sesuatu pada hari Jum'at tersebut, aku pasti memerdekakan budakku setelah hari itu. ${ }^{22}$

Lebih dari itu, ajaran Islam yang dibawa Muhammad juga secara jelas mengatur agar setiap budak dibebaskan. Semisal dalam persoalan ibadah untuk membebaskan seorang budak jika melakukan hubungan jima' di siang hari pada bulan Ramadhan, zihar kepada isteri sendiri, nazar dan sumpah yang tak terpenuhi, pembunuhan yang disengaja dan lain-lain. Firman Allah SWT dalam AlQur'an surah An-Nisa (4): 92, yang artinya:

21 Moenawar Chalil. Kelengkapan Tarikh Nabi Muhammad SAW. (Jakarta: Gema Insani Press. 2001) hlm. 339.

22 Lutfi Fathullah. Fikih Sirah (Hikmat Tersirat dalam Lintas Sejarah Hidup Rasulullah SAW). (Bandung: Mizan Media Utama. 2009). hlm. 652. 
“Dan tidak layak bagi seorang mu'min membunuh seorang mu'min (yang lain), kecuali karena tersalah (tidak sengaja), dan barang siapa membunuh seorang mu'min karena tersalah (hendaklah) ia memerdekakan seorang hamba sahaya yang beriman serta membayar diyyat yang diserahkan kepada keluarganya (si terbunuh itu), kecuali jika mereka (keluarga terbunuh) bersedekah. Jika ia (si terbunuh) dari kaum (kafir) yang ada perjanjian (damai) antara mereka dengan kamu, maka (hendaklah si pembunuh) membayar diyyat yang diserahkan kepada keluarganya (si terbunuh) serta memerdekakan hamba sahaya yang beriman. Barangsiapa yang tidak memperolehnya, maka hendaklah ia (si pembunuh) berpuasa dua bulan berturut-turut untuk penerimaan taubat dari Allah. Dan adalah Allah Maha Mengetahui lagi Maha Bijaksana”.

Islam juga memberikan motivasi yang kuat kepada para pengikutnya untuk membebaskan para budak yang mereka miliki, sebagaimana yang terdapat dalam sebuah hadits yang artinya :

"Siapa saja seorang muslim yang membebaskan seorang budak yang muslim, maka perbuatannya itu akan menjadi pembebas dirinya dari api neraka”. (HR Tirmidzi)

Kemudian, Islam yang dibawa oleh Muhammad juga mempunyai banyak aturan yang jelas berkaitan dengan persoalan perbudakan hingga ketenagakerjaan dalam berbagai teks-teksnya, hal tersebut dapat kita temui semisal dalam masalah waktu pemba- yaran upah pekerja dimana Islam menganjurkan setiap Tuan yang mempunyai pekerja untuk mensegerakan pembayaran upah "sebelum keringatnya kering”. Selain itu, beberapa sikap Islam terhadap perbudakan juga dapat diaplikasikan dalam dunia ketenagakerjaan, seperti misalnya menyikapi para budak dengan lemah lembut dan penuh kasih sayang, sebagaimana dalam sebuah hadits yang menyatakan:

"Bertaqwalah kalian kepada Allah dan perhatikanlah budak-budak yang kalian miliki”.' (Shahih Al Jaami')

Islam juga tidak memaksakan suatu pekerjaan kepada seseorang pekerja melebihi batas kemampuannya, hal ini seperti yang terdapat dalam hadits sebagai berikut :

"Budak memiliki hak makan/lauk dan makanan pokok, dan tidak boleh dibebani pekerjaan yang diluar kemampuannya". (HR Ahmad dan Baihaqi)

Kemudian terhadap para tenaga kerja, juga Islam tidak hanya memberikan aturan dalam bersikap, namun juga dalam berbicara:

"Janganlah salah seorang diantara kalian mengatakan: Hai hamba laki-lakiku, hai hamba perempuanku, akan tetapi katakanlah: Hai pembantu laki-lakiku, hai pembantu perempuanku”. (HR Bukhari dan Muslim)

Dari berbagai penjelasan tersebut, jelaslah bahwa Islam sebagai agama yang bersifat universal dan sesuai dengan perkembangan zaman tidak memungkiri dan menutup-nutipi akan adanya perbudakan dimasa lampau hingga dimasa yang akan datang dengan berbagai bentuknya. Namun disisi lain, 
Islam juga telah menentukan sikap yang sangat persuasif untuk menentang segala bentuk perbudakan dan mendukung segala bentuk pembebasan atau pemerdekaan perbudakan.

\section{Perbudakan Modern (Modern Slavery) dalam Dunia Pendidikan}

Perbudakan modern (modern slavery) didefinisikan sebagai kondisi di mana seseorang memperlakukan orang lain sebagai properti miliknya, sehingga kemerdekaan orang itu terampas lalu dieksploitasi demi kepentingan orang yang melakukan praktik perbudakan, dalam hal ini orang bisa dipekerjakan dan dibuang begitu saja seperti barang ${ }^{23}$. Eksistensi mereka sebagai budak sama saja seperti halnya benda yang bisa dimiliki, dimanfaatkan, dirusak, disakiti, bahkan merekapun bisa dijual-belikan oleh Tuannya jika diperlukan. Jiwa raga mereka dikekang dan tidak memiliki kebebasan serta berada dalam tekanan. Akibatnya adalah seorang budak tidak akan melakukan sesuatu kecuali atas kehendak tuannya. Keadaan ini justru berbanding terbalik, dan sangat berbeda dengan orang yang merdeka; bebas dan tidak dikendalikan oleh siapapun, karena jiwa raganya hanya dia sendiri yang memilikinya. Bentuk perbudakan modern saat ini tidak hanya sebatas penidasan dan kekerasan secara fisik, namun juga kekerasan berupa kata-kata, psikis dan penghancuran mental, dampak paling krusial dari perbudakan tersebut, ialah: hilangnya rasa percaya diri.

Menurut M. Yunan Nasution setidaknya terdapat tiga (3) macam sistem baru perbudakan di era sekarang:

1. Political Slavery, yaitu perbudakan yang didasarkan pada kepentingan politik. Hal

23 http://www.antaranews.com/berita/464938/ apa-itu-perbudakan-modern dikases tanggal 28-Oktober-2015 ini yang mengakibatkan satu negara (satu individu) bergantung pada negara lain (individu lain), sehingga muncul tekanantekanan yang halus dan terselubung.

2. Social Slavery, yaitu perbudakan sosial. Dalam kategori ini masuk human traficking, pengiriman TKW untuk kepentingan seksual, penjualan bayi dengan motivasi dagang.

3. Industrial Slavery, yaitu perbudakan yang timbul karena perkembangan dan kemajuan industri. Tenaga manusia dipekerjakan dipabrik-pabrik, pertambangan dan industri yang lain dengan upah minim sekedar bertahan hidup.

Untuk sektor pendidikan, perbudakan yang ada terkesan samar-samar atau keabu-abuan. Hal ini dapat terjadi pada siswa bahkan terhadap tenaga pendidik atau guru sekalipun. Bentuk perbudakan pada siswa diantaranya seperti dengan pemberian tugas secara berlebihan atau diluar kewajaran. Selain itu, perbudakan dalam dunia pendidikan adalah ketika peserta didik dipaksa untuk menguasai meteri-materi yang disampaikan guru dalam rangka mencapai indikator hasil belajar yang tertuang dalam rencana pembelajaran. Ratna Megawangi: Adakah Peluang Bagi Pembelajar Holistik" dalam Safak Muhammad (2005: 19) dalam sebuah seminar "Pro Kontra Kurikulum 2004 menyatakan bahwa:

"Sejak kelas 1 SD sampai SMA bahkan ada yang Universitas, para siswa dipaksa duduk diam mendengarkan guru, mencatat, tanpa dialog interaktif antara guru dan siswa. Selain itu siswa juga di suruh menghafal mata pelajaran yang abstrak, sehingga menghasilkan generasi robot. Oleh karena itu saya menilai wajar bila dikalangan siswa sering terdengar celotehan "Makan tuh ..... rumus-rumus!", 
atau kata-kata sejenis yang mengekspresikan betapa pelajaran yang mereka terima lebih banyak bersifat menghafal dan monoton. Sekolah juga lebih menekankan 'grade minded' untuk menentukan prestasi dan kelulusan ${ }^{24}$.

Situasi ini kemudian pada akhirnya berimplikasi pada proses belajar yang kemudian berdampak pada kualitas pembelajaran serta orientasi proses pelaksanaan yang bersifat seadanya sesuai standar kompetensi dan kompetensi dasar, serta sering hanya bersifat rutinitas, formalitas, kering dan kurang bermakna. Bahkan bermacam-macam metode ataupun strategi pembelajaran yang banyak jumlahnya hanya merupkan krayon berwarna yang ikut mewarnai sketsa yang telah ditentukan sebagai ketuntasan yang mesti dicapai siswa.

Permasalahan demikian selanjutnya melahirkan ketidakberdayaan siswa untuk mengekspresikan diri ditinjau dari sisi kebebasan di dalam pendidikan. Karena bisa saja dalam suatu materi pelajaran yang diajarkan, siswa dapat menemukan atau mengeksplorasi hal-hal baru di luar teks standar kompetensi maupun kompetensi dasar yang hendak dicapai. Pendidikan seperti ini sebenarnya telah gagal menempatkan dirinya dalam konteks pembebasan, seperti dinyatakan Ivan Illich dalam karya ekstrimnya "Deschooling Society" (1972) sebagaimana dikutip Retno S. Satmoko (1996: 150), bahwa sekolah adalah tempat yang menekan dan memaksa anakanak mempelajari hal-hal yang tidak disenangi dan dikehendaki, karena tidak efektifnya Ivan Illich menganjurkan agar sekolah seperti itu untuk dibubarkan ${ }^{25}$

24 Safak Muhammad. Kaya Tanpa Bekerja. (Jakarta: Republika. 2005). hlm. 19.

25 Satmoko, Retno. S. Pengantar Pendidikan, (Jakar-
Pengertian bebas yang dimaksud tentu bukanlah berarti makna bebas yang seluas-luasnya tanpa batas dan menganggu kebebasan orang lainnya. Namun hal ini tentu tetap pada koridor undang-undang yang berlaku serta batasan sebagai hamba Tuhan. Sehingga kebebasan ekspresif di dalam proses pembelajaran di dalam penggunaan metode sangat diperlukan, apalagi metode tersebut dilakukan oleh siswa. Selain itu peserta didik harus berpikir bebas (merdeka) dalam arti keluar dari tekanan yang membelenggu. Untuk itulah seharusnya siswa tidak diperbudak oleh kurikulum., karena kurikulum sebenarnya berfungsi sebagai standar acuan dalam mengerjakan sesuatu dan bukan sebuah teks kaku yang harus diikuti dan bersifat mengikat. Anak sudah tidak sepantasnya lagi "diperbudak" dengan kurikulum yang sangat padat, mereka bukanlah sebuah pohon yang harus melahirkan bermacam-macam jenis buah sekaligus. Disini anak hendaknya di biarkan untuk mempelajari apa yang ingin mereka pelajari (lets they learn what they want to learn), sehingga terbentuk karakter anak yang mencintai pelajarannya dan bukan dipaksa untuk mempelajarinya.

Lebih lanjut, pada bidang lain di sektor pendidikan perbudakan juga terjadi pada tenaga pendidik, khususnya pada pemberian tugas dan kewajiban bagi guru tidak tetap tanpa memperhatikan kesejahteraannya. Disatu sisi sekolah memang memiliki keterbatasan, namun disisi lain sumber daya manusia juga perlu diperhatikan. Dengan demikian, tidak hanya kaum buruh, perbudakan modern (modern slavery) juga terjadi pada guru tidak tetap yang bekerja di berbagai sektor pendidikan, bahkan hingga saat ini masih banyak

ta: Direktorat Jenderal Pembinaan Kelembagaan Agama Islam dan Universitas Terbuka. 1996). hlm. 150 . 
kita temukan pendpatan atau gaji guru tidak tetap yang digaji tidak sesuai dengan Upah Minimum Regional (UMR)

Mereka juga dieksploitasi dalam rangka mencapai hasil produksi institusi, namun disisi lain upah yang mereka peroleh justru sangat tidak adil bahkan jauh dari upah yang seharusnya mereka terima. Selain itu, sebagian dari mereka tidak diperlakukan dengan baik dalam hal pembagian tugas, mereka harus mengikuti apa yang menjadi perintah dari atasannya yang terkadang diluar kontrak yang telak disepakati. Hal ini belum ditambah dengan tugas-tugas lain yang berasal dari teman sejawat yang telah bersatus guru/ pejabat tetap di lembaga tersebut, yang jika perintahnya tidak dikerjakan akan tidak menguntungkan bagi guru tidak tetap.

Tidak hanya pada guru, dosen tidak tetap juga mengalami hal yang sama namun cenderung lebih baik. Sebagai contoh, gaji yang dibayarkan pada dosen tidak tetap atau diperbantukan di Perguruan Tinggi Negeri, biasanya hanya diterima untuk satu semester sekali. Padahal dalam satu semester atau enam bulan selama menunggu, mereka harus mengeluarkan biaya rutin berupa uang transportasi, uang makan-minum, biaya sewa tempat tinggal dan lain-lain. Itupun jika dihitung tidak dapat mencukupi pengeluaran bulanan yang harus mereka bayarkan.

Beban kerja yang tidak sesuai dengan upah yang mereka terima, juga diperparah dengan jam kerja yang terkadang tidak sesuai jadwal. Dalam beberapa kasus mereka harus bekerja lembur bahkan untuk pekerjaan yang sebenarnya bukan merupakan bidangnya. Di beberapa institusi pendidikan formal dan informal juga telah tertanam sebuah dogma bahwa seorang pekerja di sektor pendidikan harus ikhlas beramal dalam mengabdikan dirinya, meskipun disisi lain hal tersebut justru bertentangan dengan teks-teks agama yang menuntut perikeadilan antara pembayaran dengan pekerjaan yang telah mereka lakukan.

Apa yang dialami mereka memang tidaklah pantas, namun rasa malu secara psikologis terhadap diri dan keluarganya jika masih menganggur padahal mereka berasal dari lulusan sarjana membuat mereka tidak dapat berbuat apa-apa. Faktor lain berupa ketidakberdayaan mereka secara kompetensi dalam bersaing di dunia kerja menjadi alasan bagi mereka untuk tetap bertahan melalui jalan tersebut. Sebuah hal berat yang mudah ditulis dalam jurnal namun perih untuk dilaksanakan.

Selain berbagi persoalan di atas, sebagian besar guru tidak tidak tetap yang ada di Indonesia juga belum memiliki jaminan atas kesehatan diri dan anggota keluarga yang menjadi tangunggannya. Mereka harus tetap sehat untuk bekerja keras meskipun dengan gaji yang serba pas-pasan. Jika mereka sakit, selain harus mengeluarkan biaya pegobatan mereka juga harus terkena sanksi yang bisa saja menimpa mereka, mulai pemotongan gaji sampai pada pemecatan. Para guru tidak tetap ini juga sudah dapat dipastikan tidak akan mendapat tunjangan hari tua baik berupa pesangon apalagi dalam bentuk uang pensiun. Resiko ini justru berbanding terbalik dengan waktu, tenaga dan pikiran yang telah mereka curahkan selama mengabdi pada instansi dimana mereka bekerja.

Beberapa bentuk perbudakan yang dijelaskan di atas sudah sepantasnya menjadi pertimbangan tentang bagaimana membentuk regulasi yang lebih baik mulai dari tahap perekrutan sampai pada tahapan pembentukan output kependidikan itu sendiri. Sehingga perbudakan modern (modern slavery) dalam berbagai bentuknya dapat dihindari untuk terjadi dalam dunia kependidikan. 


\section{PENUTUP}

Perbudakan sudah ada dalam perjalanan tradisi agama-agama di dunia sebelum kelahiran Muhammad. Bahkan kedatangan Muhammad inilah dianggap sebagai akhir dari zaman perbudakan. Banyak tokoh setelah Muhammad kemudia bangkit dan melawan perbudakan, semisal di era modern muncul nama Malcolm Little/ El-Hajj Malik El-Shabazz (1925-1965), Martin Luther King (1929-1968) dan Nelson Mandela (19182013) yang pada masanya yang telah berjuang atas nama kemerdekaan manusia dari perbudakan.

Apa yang patut kita semua waspadai pada era sekarang ini adalah bentuk-bentuk lain dari perbudakan sebagaimana telah disebutkan di atas. Hal ini sebagaimana pesan yang terkandung dalam ajaran Islam tentang persaudaran, kesejajaran dan saling mengasihi antar sesama. Disinilah Islam menunjukkan sikap menjunjung nilai-nilai humanisme pada diri manusia itu sendiri serta sangat menentang praktek perbudakan dimanapun dan dalam bentuk apapun.

Tindakan-tindakan nyata atau real actions pada konteks anti perbudakan yang dapat dilakukan saat ini diantaranya adalah dengan melakukan pembuatan dan penegakan hukum ketenaga-kerjaan (labour law) yang adil dan melindungi hak-hak para tenaga kerja serta melalui pengawasan yang ketat terhadap pelaksanaannya. Hukum tersebut harus mengatur jam kerja yang logis, pemberian upah minimum yang layak, dan pemberian fasilitas-fasilitas pendukung lainnya seperti asuransi kesehatan, tunjangan hari raya, dan sebagainya.

\section{DAFTAR PUSTAKA}

Abineno, J. L. Ch. 2005. Diakeger (Diakonia dan Diakonat Gereja). Jakarta: BPK Gunung Mulia.

Armansyah. 2008. Ramalan Imam Mahdi Akankah ia Datang Pada 2015. Jakarta: Serambi.

Armstrong, Karen. 2003. Perang Suci dari Perang Salib hingga Perang Teluk. Terj. Hikmat Darmawan. Jakarta: Ikrar Mandiriabadi.

Az-Zabidi, Imam. 2008. Ringkasan Shahih Al-Bukhari. Bandung: Mizan Pustaka.

Bahar, Ahmad. 2005. Harta Karun dari Timur Tengah. Yogyakarta: Penerbit Kanisius.

Balitbang, Tim. 2007. Meretas Jalan Teologi Agama-Agama di Indonesia: Theologia Religionum. Jakarta: BPK Gunung Mulia.

Barclay, William. 2010. Pemahaman AlKitab Setiap Hari: Surat Yakobus 1 dan 2. Jakarta: Gunung Mulia.

Berkof, Hendrikus. 2009. Sejarah Gereja. (disadur oleh Enklaar). Jakarta: Gunung Mulia.

Bertens, K. 1999. Sejarah Filsafat Yunani. Yogyakarta: Kanisius.

Chalil, Moenawar. 2001. Kelengkapan Tarikh Nabi Muhammad SAW. Jakarta: Gema Insani Press.

E. B., Surbakti. 2008. Benarkah Injil Kabar Baik?: Bagaimana Menyatakannya dalam Perspektif Lokal. Jakarta: Gunung Mulia. 
End, Van den \& Jonge, Christiaan de. Sejarah Perjumpaan Gereja dan Islam. 1997. Jakarta: Sekolah Tinggi Teologi Jakarta.

Fathullah, Lutfi. 2009. Fikih Sirah (Hikmat Tersirat dalam Lintas Sejarah Hidup Rasulullah SAW). Bandung: Mizan Media Utama.

Hitti. Philip K. 2002. Terj. Yasin dan Riyadi. Hiistory Of The Arabs. Jakarta: PT. Serambi Ilmu Semesta

Husaini, Adian. 2005. Wajah Peradaban Barat dari Hegemoni Kristen ke Dominasi Sekular-Liberal. Jakarta: Gema Insani Press.

Martasudjita. E. 2003. Pelayanan yang Murah Hati. Yogyakarta : Kanisius.

Miller, Stephen M. 2009. User's Guide to Bible. Yogyakarta: Kanisius.

Muhammad, Safak. 2005. Kaya Tanpa Bekerja. Jakarta: Republika.

Napel, Henk Ten. 2006. Kamus Teologi. Jakarta: Gunung Mulia.

OFM, C. Groenen \& Leks, Stefan. 1987. Percakapan tentang Mengikuti Yesus. Yogyakarta: Kanisius.

Pfitzner, V. C. 2006. Kesatuan dalam Kepelbagaian: Ulasan atas 1 Korintus. Jakarta: Gunung Mulia.

Rangganis, Ratna. 2013. Sosok di Balik Perang. Jakarta: Raih Asa Sukses.

Satmoko, Retno. S. 1996. Pengantar Pendidikan, Jakarta: Direktorat Jenderal Pembinaan Kelembagaan Agama Islam dan Universitas Terbuka.
Suharyo, Ignatius. 2009. Gereja yang Melayani dengan Rendah Hati. Yogyakarta: Kanisius.

Sutardi, Tedi.2007. Antropologi: Mengungkap Keragaman Budaya. Bandung: PT. Setia Purna Inves.

Thosibo, Anwar. 2002. Historiografi Perbudakan Sejarah Perbudakan di Sulawesi Selatan Abad XIX. Magelang : IndonesiaTera.

Yasin, Ahmad Hadi. 2010. Meraih Dahsyatnya Ikhlas. Jakarta: AgroMedia Pustaka. 